\title{
Creative Pedagogy: 30 Years and Counting (In Foreign Language Education and Beyond)
}

\author{
Andrei G. Aleinikov ${ }^{1, *}$ \\ ${ }^{1}$ International Academy of Genius, 2231 Segundo Ct., Unit 2, Pleasanton, CA 94588, USA \\ *Corresponding author: International Academy of Genius, 2231 Segundo Ct., Unit 2, \\ Pleasanton, CA 94588, USA. Tel: 1-831-297-0886 E-mail: aleini13@outlook.com
}

Received: January 19, 2020 Accepted: March 12, 2020 Published: March 25, 2020

doi:10.5296/ije.v12i1.16979ＵRL: https://doi.org/10.5296/ije.v12i1.16979

\begin{abstract}
This paper provides a brief overview of Creative Pedagogy as an educational trend, which was introduced over 30 years ago, in 1989, and has spread extensively around the world since that time. It also demonstrates Creative Pedagogy's application to Foreign Language Education (FLED) and other subjects. Originally, just as creative thinking is opposed to critical thinking, Creative Pedagogy was opposed to Critical Pedagogy, but it was defined as a formula of invention - absolutely obligatory in patent description in technology and the first time in the history of education - and this made it opposed to all other types of pedagogies. With the advent of Sozidonics, the science of creativity, where creativity was given a scientific definition, Creative Pedagogy became the only trend in education that is technologically-defined and scientifically-based. When united with Creative Andragogy, it became Creagogy - a generic science of creative education.
\end{abstract}

Keywords: creative Pedagogy, creativity, Pedagogy, ideal learner, ideal education model, Genius Education Methodology, Creagogy 
"It takes courage to be creative; just as soon as you have a new idea, you're in a minority of one."

Dr. E. Paul Torrance

"Creative activity could be described as a type of learning process where teacher and pupil are located in the same individual."

Arthur Koestler

\section{Introduction}

Recently, after receiving some information on Creative Pedagogy (Aleinikov, 2013a), one educational leader asked the author at a conference, "Could you describe in simple terms, what the problems with adult students are, what you did, what the results were, and why?"

Great questions. On one hand, such a request is understandable since, though Creative Pedagogy is celebrating 30 years of history (the first article on the subject was published in 1989), it is still near impossible to find the answers to these questions in the author's previous $150+$ publications in 9 languages and 13 countries, including an article in the Encyclopedia of Creativity (1999a), two articles in the World Education Encyclopedia (2001), and seven articles in the Springer Encyclopedia of Creativity, Invention, Innovation, and Entrepreneurship (2013, 2017).

The short answers to these four questions, in very simple terms, are:

\section{- are the problems with adult students?}

The problems with adult students are numerous and multifaceted and result in high attrition rates, low performance, and low achievement.

\section{- did I do?}

I researched the issue and discovered one common cause behind all problems (mindset, Uznadze, 1961; Lange 1888), designed special methods of mind-setting, or mindset (re)orientation, and then developed a full-scale educational methodology (Creative Pedagogy) based on this discovery.

\section{-What were the results?}

As a result, $99.6 \%$ of adult students performed

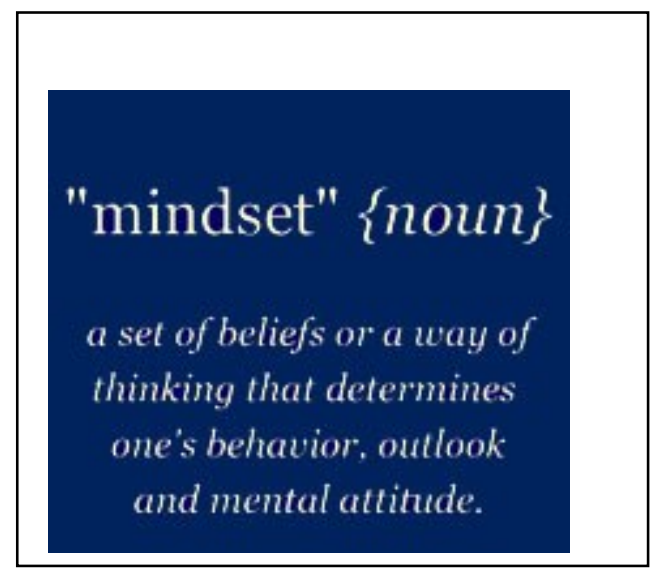
brilliantly and gave positive evaluations of the courses and programs.

\section{-Why?}

This is because changing the mindset pre-determines all other changes in thinking and behavior. Changing the settings from closed to open, from negative to positive, from passive 
to active, from disinterested to interested, and from unmotivated to motivated, etc. leads to an ideal learner (IdeaLearnerC) in every classroom. This ideal learner then eagerly uses the creativity tools for accelerated learning and self-development.

It should be noted that metaphorically speaking, the changing (reorientation) of the mindset prevents and cures the disease instead of treating the symptoms. A quick and precise "injection of creativity" into the teaching/learning process changes the mindset system (a set of mental and behavioral responses to external influences) exactly as a vaccination changes the immune system (a set of biological responses to external influences). As this scientific analogy demonstrates, the discovery and introduction of Creative Pedagogy to education is the same as the discovery and introduction of vaccination to medicine by Edward Jenner in 1599. Thus, linguistically, just as the new terms immunization and vaccination were introduced for these new types of medical treatment, the term Creative Pedagogy was introduced for this new type of teaching.

On the other hand, these short answers may seem too short to be useful since some professionals are teaching math, while others teach languages. Creative Pedagogy can be applied to all fields because it starts earlier and goes deeper than specialization; therefore, it is appropriate for music, math, pharmacology, etc. However, this study will deal specifically with language samples and language teaching because it was the first, and continues to be the main, domain of the author.

Moreover, these questions push further. Since a creative person always does more than is asked of them, maybe it is a good time to put everything in perspective and share it from the point of view of a person who once said, "A" or "Alpha." As such, this article explains the "What?, What?, What?, and Why?" as related to foreign language education (FLED) in its practical orientation (with minimum theory) and illuminates the bigger picture: a bird's-eye view of Creative Pedagogy.

\subsection{Concrete Answers to Concrete Questions}

\subsubsection{What Are the Problems with Adult Students?}

It should be noted that some students show excellent or at least average performance and do not experience any problems; however, many do not, and the term "problems" applies mostly to those who perform below average. The problems of education, in general, are abundantly described in the literature and online, including, negative environments, poor teacher training, insufficient funding, and many more. For example,

In the U.S. today, problems of education relate to funding, teacher quality and the status of the teaching profession, student academic performance and standardized testing, racial imbalances and equal educational opportunity, and the curriculum in relation to labor force needs and global competition. New problems, such as teacher shortages, overcrowded and unsafe schools, and unequal access to educational technology join other perennial issues in education such as gender bias and the bilingual education debate. The educational system as a social institution and individuals' educational experiences and levels of attainment are key factors in 
addressing other social problems. [Retrieved from https://pacs.ou.edu/media/filer_public/3a/26/3a265cd5-c6b0-40dc-859b-ab16a280b3 9b/fa19_dm5013lk.pdf or in https://niagarafallshypnosiscenter.com/to-talk-about-education/ -- on Mar 10, 2020].

All of these problems result in low performance, poor discipline, high levels of dropouts (attrition)-sometimes over 20\% [See the Texas example at https://files.eric.ed.gov/fulltext/ED591733.pdf Retrieved on Mar 10, 2020] and even 40\% [See, for example, https:/www.washingtonpost.com/education/2019/09/10/a-dereliction-duty-college-dropout-s candal-how-fix-it/ -- Retrieved on Mar 10, 2020]_drugs, crime, teenage pregnancy, high illiteracy rates, and so on. The most common influences to blame for these depressing educational realities are family members, peers, teachers, administrations, governments, and more. In addition to these common problems, the problems faced by adult learners include life situation pressures, time pressures, health-related (aging) issues, fears, insecurities, past failures in schooling, boredom, resistance to learning, and so on, as follows:

There are many issues that might hinder the progress of some adult learners: health-related issues, especially in older students, family and job issues, day care, work schedules, divorce, traumatic events, etc. Transportation, schedule changes, and finances can often keep students from attending class at all. Lastly, students may be frustrated by the difficulty of the work, or impatient with the pace of their success they may have reached a "learning plateau" and feel that they "aren't getting anywhere." [See numerous sources, like https://careerfoundry.com/en/blog/career-change/the-challenges-of-being-an-adult-le arner-and-how-to-overcome-them/ or in https://edservices.wiley.com/5-engagement-factors-adult-learners/ -- Retrieved on Mar 10, 2020]

\subsubsection{What Did I Do?}

Firstly, I stopped blaming anybody for the quality of students coming to my classroom and refrained from any pre-judgment or judgment (criticism), instead, taking on the responsibility myself. If a student does not perform at the peak of his/her abilities, it is $m y$ fault (not that of the student, nor family or peers, nor the government); therefore, it is I and not anybody else, who must find, invent, and create a method or technique to engage this student the next day and every day thereafter: It was a change in $m y$ mindset.

Second, I researched and analyzed the problems of education and came to the conclusion that all of them find their way to the student's psychology and are based on the mindset that pre-determines the student's attitude and motivation. I then put forward a hypothesis that if we (teachers, professors, and leaders) could find methods of mind-setting that would change this attitude and motivation, we would be able to cure the educational "disease" instead of treating the "symptoms" of poor discipline, low interest, and others. Finally, I developed these new methods and tested them in the classrooms of the Military Institute of Foreign Languages, Moscow. 
The results were so overwhelmingly positive that I was asked to describe the new methodologies for other instructors and professors to follow and granted three years of postdoctoral research by the leadership of the Institute. My research led to the creation of the new trend in education, named Creative Pedagogy, then later Creative Andragogy (a generic name for both is Creagogy [Aleinikov, 1998]).

This new trend was described in a formula of invention. The first article on Creative Pedagogy was published in 1989 by the Higher Education Bulletin (Moscow, Russia), and this publication began the spread of the new term and concept worldwide.

\subsubsection{What Were the Results?}

$99.6 \%$ of adult students (age 16-76, about $70 \%$ of them were military staff), liked the new way of learning. These students showed outstanding educational results: In addition to higher test and exam scores, they created new props, theories, booklets, and books. Students gave the highest possible evaluations of the new courses and programs, which led to the author receiving teaching awards and nominations.

Creative Pedagogy was further tested (and perfected) in the Military Institute of Foreign Languages (Moscow, Russia), Russian Academy of Sciences (3 Centers, Moscow, Russia), Center for Pedagogic Innovations (5 colleges, Krasnodar, Russia), Air War College (USAF Air University, Maxwell AFB, Alabama), Auburn University (Montgomery, Alabama), Troy University (Montgomery, Alabama), Junior NCO Academy (Gunter AFB, Alabama), JROTC Instructors (USAF Air University, Maxwell AFB and Garmisch, Germany), and the University of Cincinnati (Ohio).

Via the training of teachers, instructors, professors, and administrative leaders, Creative Pedagogy (actually, Creative MetaPedagogy, or teaching teachers how to teach creatively, i.e., the train-the-trainer level) spread to the schools, colleges, universities, and educational systems of Germany, India, Pakistan, Russia, Singapore, South Africa, Thailand, and the USA. The new courses "Psychology of Creativity" (PSY3390) and "Foundations of Creative Education" (EDU6625) were introduced to the curriculum of Troy University (Montgomery, Alabama), while research and literature on Creative Pedagogy was growing globally, including new encyclopedias and dictionaries, conferences, and dissertations, etc. Furthermore, a new online Encyclopedia of Creative Pedagogy (specifically dedicated to Creative Pedagogy and edited by V. V. Popov) is being published in Russia.

\subsubsection{Why?}

Creativity is one of the most highly regarded human abilities (see the literature on geniuses and creative solutions in science, technology, arts, business, and education - see Encyclopedias of Creativity, Aleinikov, 1999, 2013); thus, excluding, minimizing, and suppressing the creativity factor from the traditional educational process (schools), which Dr. E. Paul Torrance even called "the $4^{\text {th }}$ grade creativity slump," led to numerous problems in education. Only the best teachers continue to encourage and nurture creativity in the classroom despite the test-, exam-, and score-dominant educational culture, allowing their students to blossom, while they themselves gain well-deserved recognition. Often, however, 


\section{Macrothink}

there is no theoretical explanation for this scenario-they are simply called "talented teachers."

Creative Pedagogy provides an explanation, highlighting that creativity is much broader than the arts. It is the self-multiplying reflection: reflection squared (the reflection of reflection), reflection cubed, reflection quadrupled. Creativity is the only feature that separates humans from the animal world, and it is exactly what accelerates the development of the human world over the speed of development in the "natural" animal world. The scientific view on creativity states that it is the acceleration of the organization process (Aleinikov, 2013c, 2013f).

Figure 1, taken from the article on creativity, the main concept of the Springer Encyclopedia of Creativity, Invention, Innovation, and Entrepreneurship (Aleinikov, 2013c) illustrates the essence of creativity.

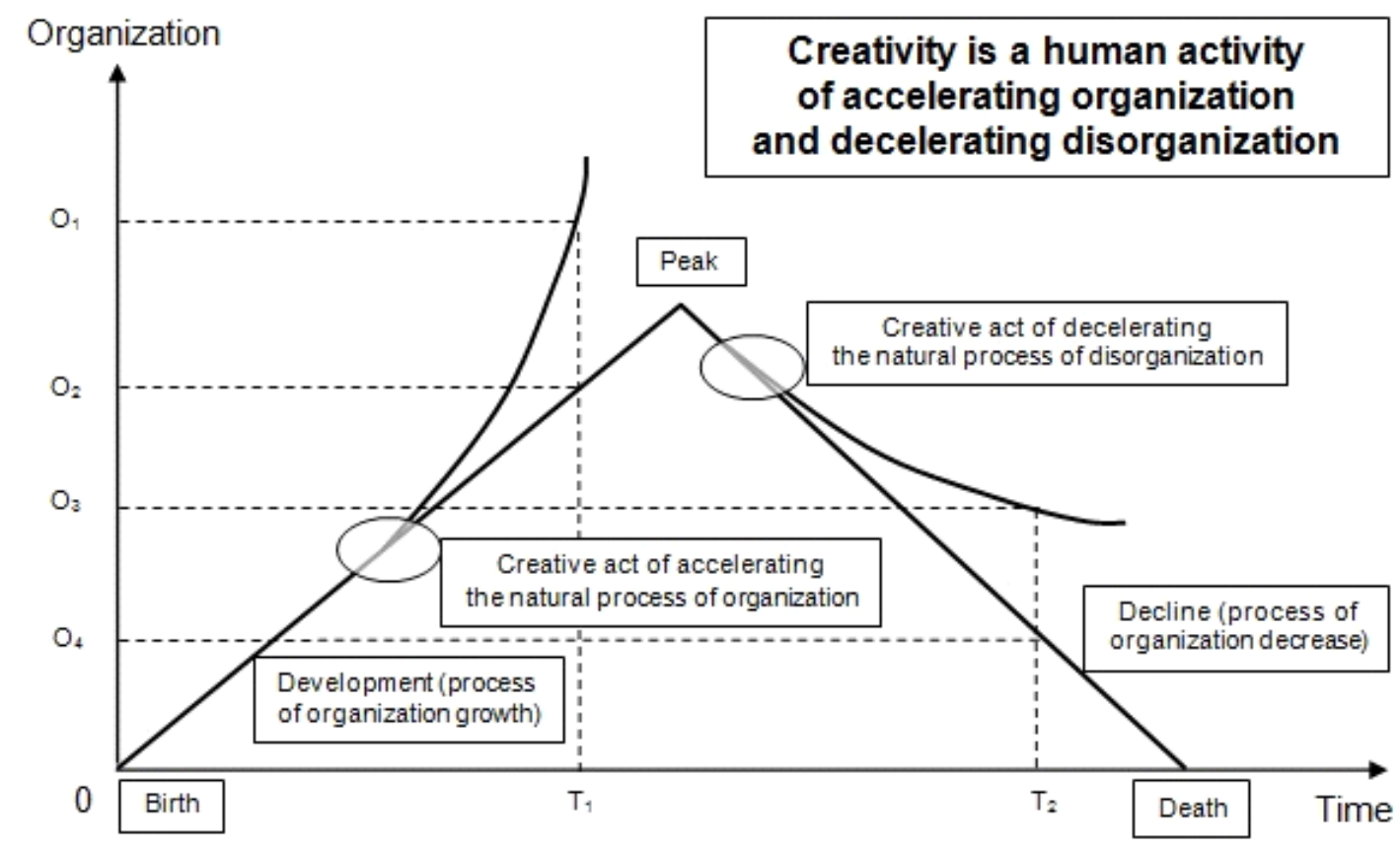

Figure 1. The Essence of Creativity.

Note: See how at a certain moment of time $\left(\mathrm{T}_{1}\right.$ or $\left.\mathrm{T}_{2}\right)$, the organization level $\mathrm{O}_{1}$ (accelerated development) is higher than $\mathrm{O}_{2}$ (natural speed development), and the organization level of $\mathrm{O}_{3}$ (restoration, repairing to decelerate the decline) is higher than $\mathrm{O}_{4}$ (natural speed decline) (Aleinikov, 2013c, 2013f).

Learning is the process of organizing the human mind; therefore, introducing the creativity factor (with all the knowledge of creativity gained in the last century - See Encyclopedias of Creativity, Aleinikov, 1999a, 2013) to the educational process is the way to accelerate 


\section{Macrothink}

International Journal of Education

ISSN 1948-5476 2020, Vol. 12, No. 1

success. The mindset reorientation from "traditional" learner to "creative" learner opens a person's mind to new possibilities, boosts interest and self-expression, encourages self-development, and leads to the accelerated acquisition of the study material and, therefore, better learning results.

Creative Pedagogy offers:

- a new goal of education (to create a creative learner)

- its own techniques, methods, and methodologies of influencing learners to make them Ideal Learners

- a model of Ideal Education, where creativity and innovation take the upper two levels out of five (Aleinikov, 1999b) and methodologies that precisely follow the model

- a way to begin deeper than the traditional teaching process, at the nonverbal level of communication to reset the mindset

- a way to develop verbal communication into Super Effective Communication (Aleinikov, 1996)

- creativity-boosting methods that apply to the learning material, thus engaging the vast potential of human being growth that usually remains untapped

- a way toward innovations, explained differently (Aleinikov, 2013c), and even some strategies for living a genius life (Aleinikov, 2013e, 2002).

- Inspired and nurtured as creative learners, students perform at their best, which is why the outcomes of learning are so different.

\section{The Practical Side: Foreign Language Learning}

In foreign language education (FLED), if you ask teachers some questions about the goals of educations, put them in the left column of the table and then place creativity categories into the right column, you will see their correlation: 


\section{Macrothink}

Table 1. Correlation of Foreign Language Learning and Creativity Categories

\section{Foreign Language Learning}

Main Categories of Creativity

(Measurable - tested in the Torrance Test of Creative Thinking, [TTCT])

- Would you like your students to have fluency in speech?

-Would you like your students to be able to te, to add details, and to develop their statements?

- Would you like your students to be original in their conversations, compositions, and presentations?

- Would you like your students to have a flexible mind to understand humor, to make jokes, and to have fun in the classroom?

\section{Any Subject Learning}

- Would you like to have students who are willing and motivated to change and adapt themselves?(Aleinikov, 2003)

-Would you like to have students eager for new experiences, new environments, new language systems, new cultures, new beliefs, and new conceptual systems? (Ghonsooly \& Showqi, 2012)

Fluency: The number of ideas or solutions

Elaboration: The amount of added details in developing the point

Originality: Rarity of ideas (as opposed to those frequently used)

Flexibility: The number of different categories in a response

\section{Creativity Essence (Immeasurable)}

Openness for change and adaptability (e.g., positive mindset, attitude)

Divergent thinking is often viewed as "creative" thinking because it diverges from the trivial, usual, traditional, customary, and established (see the two-stage Great Idea Model of Creativity (Aleinikov, 1999b), where the mind diverges from the beaten path and then returns).

\section{Any Subject Learning}

- Would you like your students to work hard (to make your work easier)?

- Would you like your students to have higher achievements?

- Would you like your students to be enthusiastic (inspired) and for every class. to be joyful and memorable?

\section{Creativity "Bonus" Products}

When people create something (in the process of a creative act), they are involved and intrinsically motivated that they work day and night.

Memorized from: Audio channel - 10\%, Visual $-15 \%$, Hands-on $-40 \%$, Teaching $90 \%,--$ this is common knowledge!

We add: Creative activity $-100 \%$

Creativity and innovation bring happiness, inspiration, and joy. They create new products and, therefore, great memories. 


\section{Macrothink}

On the basis of Table 1, a teacher (instructor or professor) can make a choice between going:

- From FL learning (or any learning) to higher creativity (from left to right) (Ghonsooly \& Showqi, 2012), or

- From teaching creativity to higher results in FLED and any subject learning (from right to left).

The first direction is called traditional pedagogy, and in FLED it may lead to higher creativity (depending on the teacher), although in some other subjects that require precise answers or rote learning, it usually leads to a sharp decline in creativity (the infamous " 4 th -grade creativity slump" mentioned above).

The second direction is called Creative Pedagogy (Creative Andragogy or Creagogy [Aleinikov, 1998]).

\subsection{The Structure of Creative Pedagogy}

There are three layers of methods within the creative orientation methodology, as below. This list is taken from the article "Creative Pedagogy" in the Springer Encyclopedia of Creativity, Invention, Innovation and Entrepreneurship (Aleinikov, 2013a). Detailed explanations can also be found in the book MegaCreator (Aleinikov, 1999b).

2.1.1 The Three-level Methodology of Creative Pedagogy

Object-oriented methods (OOM)

- Morphological analysis

- BAMMA (Brainstorming Advanced by Morphological Matrix Analysis)

- Focal object

- Fantastic analogy

- Personal analogy

- Symbolic analogy

- Title (+ Non-scientific cut)

- Checklist

- Semiotic modeling

- Dynamization

- Vitalization

Subject-oriented methods - open (SOM-o)

- Method of paradox pedagogic inversion

- Method of extra difficulties 


\section{Macrothink}

- Method of time limitations

- Method of space limitations

- Method of substance limitations

- Method of stupid limitations

- Method of extra variants

- Method of dramatization

- Method of absurd

- Method of unexpected prohibitions

- Method of insufficient information

- Method of excessive information

$\underline{\text { Subject-oriented methods - closed (SOM-c) }}$

- Omitation - the universal method of creativity formation (Aleinikova, Aleinikov, 1991)

- Method of highest (genius) orientation (GEGA [Genius Expectations, Genius Achievements]. Modified from TESA [Teacher Expectations, Student Achievements] (Aleinikov, 2008)

- Method of applied nonverbal dominance (MANDo, Aleinikov, 1997, 2007)

The list includes some well-known creativity-boosting methods, such as morphological analysis (Zwicky, 1957) and analogies (from Synectics, Gordon, 1961), some methods developed by educators (Moliako, 1985), and methods designed by the author (in bold, most described in Aleinikov, 1999b).

In the structure of the lesson, course, or program, the first group of methods (object-oriented methods) occupies the central part (line three in Figure 2 below), while the second and third group (subject-oriented methods) are used at the beginning and the end. Thus, the structure of the teaching influence may be seen as follows: 


\section{Macrothink}

International Journal of Education

ISSN 1948-5476
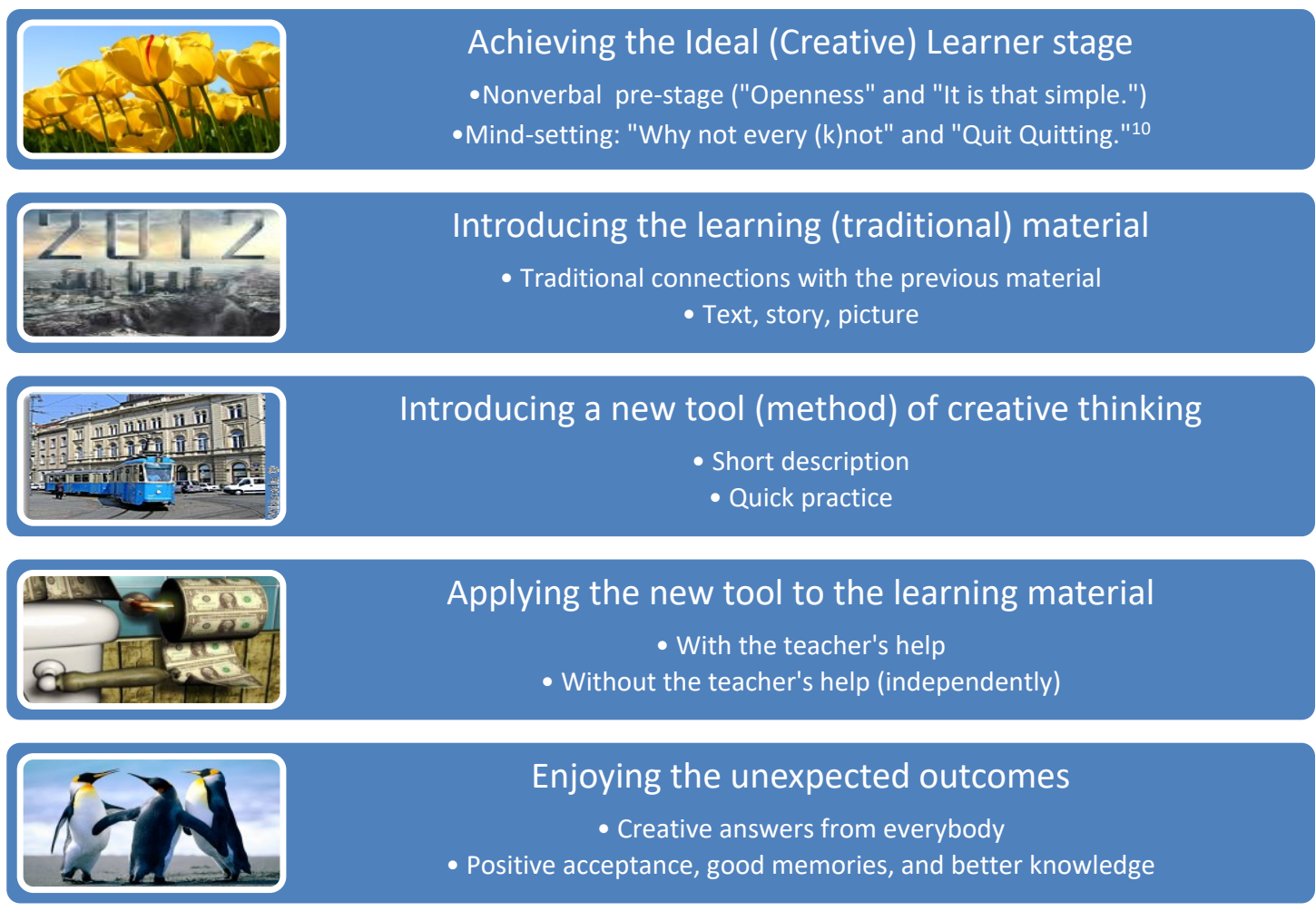

Figure 2. The Sequence Structure of Creative Orientation.

The sequence structure in Figure 2 shows very briefly how a traditional lesson can be linked to creativity. It works in a fractal manner: The same structure is applicable for lessons, courses, and programs.

Since the stages shown above coincide with the levels in the Model of Ideal Education, the process can be seen as:

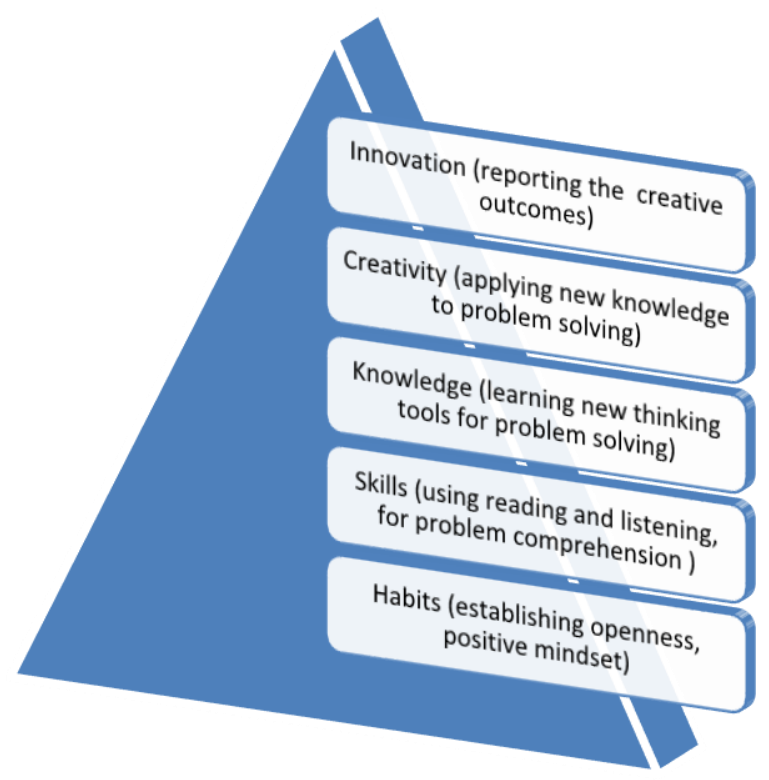

Figure 3. The Structure of Creative Orientation in the Model of Ideal Education 


\section{$\triangle 1$ Macrothink}

Figure 3 shows how the five stages of the Ideal Education Model (habits, skills, knowledge, creativity, and innovation) predetermine the flow from the lowest to the highest levels.

Finally, for those who prefer to see the conceptual volumes, it is useful to know that the process of changing the curriculum is called "creative orientation." The program in linguistics, for example, was called creatively oriented linguistics. Due to the fact that creative aspects fill the entire class, course, or program, including the side margins where deviations happen, they may be shown as below in Figure 4.

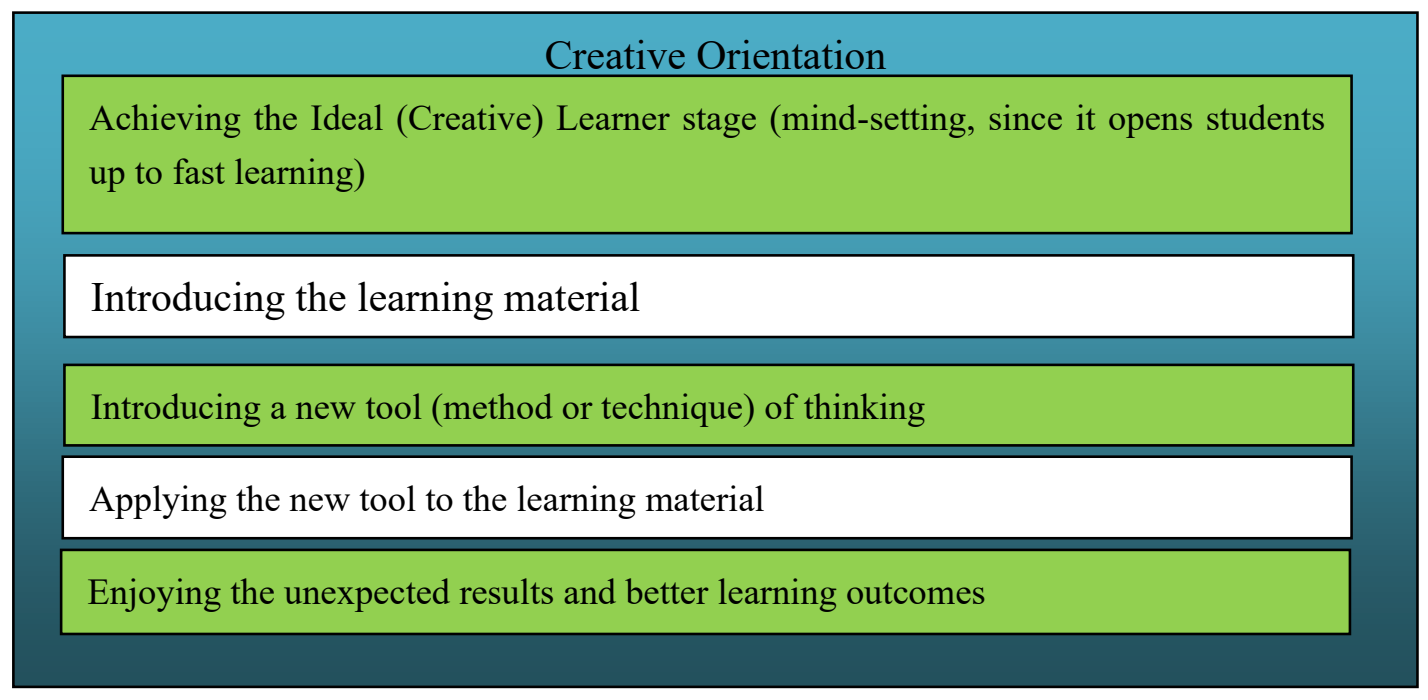

Figure 4. The Structure of Creative Orientation as a Conceptual Frame

Figure 4 looks like a frame and may be called a "frame of reference" or "conceptual frame." When Creative Pedagogy made its first steps, we used this structure to explain it to teachers. Moreover, in several programs, in collaboration with other professors who wanted to understand the differences of the new approach, we made just the first class "creatively oriented," then the middle class, and finally the last class of the entire program, which was enough for students to write exclusively positive feedback for the entire program.

Of course, establishing openness and positive mind-setting takes time, but it takes less and less time with every class because it becomes a habit ( $1^{\text {st }}$ level). Learning a new method or technique ( $3^{\text {rd }}$ level) also takes less time because students are extremely interested and grasp it with great pleasure: They begin to collect methods and to teach them to others, too. Therefore, if educators are concerned about the extra time needed for "creativity" (for example, stating, "We do not have time for creativity"), it is an unfounded excuse: In reality, creativity saves time. The new approach totally eliminates the need for disciplinary actions for students being late (special method), disinterested, inattentive, impolite, or too talkative, etc., thus saving the time that is usually wasted on disciplinary actions and ensuring the official learning time (e.g., the academic hour/semester/year) is more efficiently used. Exactly in accordance with the new definition of creativity as accelerating organization (see 
Figure 1), the creativity of the teacher accelerates the learning process, while many disciplinary actions actually slow this process. Thus, with creativity, the learning process moves to another level, that of higher organization: an interested, all-involving, joyful process in which teachers and students are creative participants.

This is where the ideal final result (IFR) of Creative Pedagogy, to create a creative learner, is achieved because students internalize those methods and techniques they learn from the teacher and reach the level perfectly depicted by Arthur Koestler, the classicist of creativity studies, as, "Creative activity could be described as a type of learning process where teacher and pupil are located in the same individual." Nothing can be more beautiful or satisfying than the view of students joyfully studying the subject you teach and creating new props, books, and products to help future students, thus becoming and being creative people.

\subsection{The Origins of Creative Pedagogy}

Historically, Creative Pedagogy grew out of Creative Linguistics (1988) (Aleinikov, 2013b) and employs the major categories, models, and conclusions of Creative Linguistics research. The main achievement of Creative Linguistics was to demonstrate that every speech act is a creative act (although the rate of creativity may be different). It is a cornerstone for FL learning, where students "create" their monologues, dialogues, new biographies, new personalities, new realities, and, consequently, their new life.

The first traces of Creative Pedagogy, in fact, date back to Socrates, who taught his students to think and to "create" their own answers rather than repeat what was said by others. Meanwhile, brilliant teachers of the past, such as Comenius, Dewey, Pestalozzi, Montessori, Steiner, Vygotsky, and many others, no matter what social system they belonged to, were an example of teacher creativity in the classroom and called for independent thinking (creativity), originality (creativity), courage (creativity, see the epigraph). Creative Pedagogy has generalized this creative effort, explained it, and focused it like a laser beam on the educational problems of the present.

\subsection{Applications of Creative Pedagogy}

As opposed to Critical Pedagogy, which emphasizes critical thinking (see Wikipedia), Creative Pedagogy explicitly aims at, explains, and teaches higher creativity. In this case, a teacher knows what creativity is, teaches it (extra material), and, as a result, nurtures an Ideal Learner (who is open, interested, enthusiastic, and eager to work hard, etc.) in the classroom much faster. The subject of study does not matter; it is the methodology that is important. Creativity applied to the process of education (as any creativity, according to the new definition) accelerates learning, and the results are exciting for all.

\subsubsection{Examples of Creative Pedagogy Applications}

After being introduced into the theoretical courses and programs (Theoretical Grammar, Lexicology, and Interpretation Theory) that became the leading courses in the Military Institute, Moscow, Creative Pedagogy was applied to the practical courses, Speech Practice and Military Translation. Later, as a pilot experiment, a special Hyper-Efficient Language 
Program (HELP) was developed to overcome the first, often most difficult, stage in learning and accelerate language acquisition. The first English programs for Russian learners provided students with over 2,000 words and expressions in 10 days ( 4 hours $\times 10$ days $=40$ hours) and the ability to communicate with (and understand) native foreign-language speakers; in other words, students were able to learn about 200 words per day on average. Due to this speed of learning a foreign language, the author of the Creative Pedagogy methodologies was asked to license them to the "Professional" Foreign Language Center in Moscow, where 40 languages are taught. The methodologies developed for HELP were later used by the Indian Navy (Bombay) to teach American professors, senior military officers at the Air War College, and all levels of Russian students at Auburn University, Montgomery, Alabama (Aleinikov, 1995). Creative Pedagogy methodologies were also applied to the courses Effective Communication (COM1110), Word Origins and Usage (ENG2210), History of Russia (HIS 3333, 3335, 5333, 5335), Psychology of Creativity (PSY3390), and Foundation of Creative Education (EDU6625) at Troy University, Montgomery, Alabama.

In addition to the adult education domain, which is more aptly described as the Creative Andragogy domain, Creative Pedagogy was intensively used to help "troubled kids" or at-risk children in Singapore, South Africa, Thailand, and the USA. The Genius Education Methodology (GEM) was successful in special schools (such as the New Challenge School, Montgomery, AL), drug rehabilitation centers (such as the John Greening Center for Youth on Chemical Dependencies, Kansas City), and more. GEM was labeled "the GEM of education" by the media when reporters discovered that a 2.5 -day pedagogical intervention in one Singapore preliminary (elementary) school, where 13 of the weakest students had been selected as "doomed to fail," helped these students pass all 52 exams [4 state exams (Math, Science, English, Mother Tongue) x $13=52$ ] just a few months after this one-time intervention, representing a $100 \%$ success rate for the program (a YouTube Presentation about this Intervention can be seen on https://www.youtube.com/watch?v=RcZTJZLL_aI Retrieved on Mar 10, 2020.

It is worth to know that Mrs. Ramos, who was so instrumental in creating this class for children and checked them after, was the first Creative Pedagogy teacher in Geography, became the best teacher in her school, was sent to work for the Ministry for Education, created a seminar for the best teachers in Singapore and look at the result. Mrs. Ramos herself was selected to helps the Minister for Education handle the Presidents Best Teaching Awards, She and her husband were sent to the USA, to the only College that awards Master's Degree in Creativity - Buffalo State College, State University of New York, She received the 2006 Best Master's Thesis Award (See https://digitalcommons.buffalostate.edu/creativetheses/29/ Retrieved on Mar 10, 2020), them she followed with the Doctorate Degree in Texas. Now both Suzanna and her husband, Hector, are Drs. Ramos! This is how Creative Pedagogy changes the lives. Oh, it is worth to mention that one of the 20 teachers that studied Creative Pedagogy in Singapore received the President's Award - the highest award of the country in a couple of years. This is how the country wants to save their dropouts from dropping from school. And the author would like to ask readers to guess, what is the attrition rate in Singapore? You will not believe it - it is $3 \%$ ! And they consider it large. For comparison, as 
it was shown above, in the USA it is $15-40 \%$, but seemingly only reporters worry about it. This is what students write about Mrs. Ramos: https://steveranson.wordpress.com/2007/01/14/my-teacher-mrs-ramos/amp/ retrieved on Mar 10, 2020. People like Dr. Ramos and 20 teachers trained in Creative Pedagogy lead Singapore to become the nation of geniuses - exactly as it was predicted and programmed in the work earlier (Aleinikov, 2003).

\subsection{The Spread of Creative Pedagogy}

The programs for teachers and principals (Creative MetaPedagogy) that have taken place in schools, colleges, universities, academies, and centers in Pakistan, Russia, Singapore, South Africa, Thailand, and the USA, as well as keynote speeches and conference presentations, have inspired hundreds of educators to change their mindset in order to, subsequently, be able to change the mindset of their students and help them achieve peaks in their development.

\subsection{Creativity in Curriculum Development}

Finally, the question is whether Creative Pedagogy is effective only in the classroom or whether it can be useful for distance learning? It is certainly also successful in distance learning, self-learning, self-training, CD-ROM-based, and online learning. A creative lesson - and the creative teacher behind it - is more interesting and, therefore, more attractive for the learner. Since interest is the key, this accelerates the learning process.

Every day brings new technical opportunities: Web 2.0 Tools are growing in number and possibilities. The most popular example of Web 2.0 tools is Wikipedia, where any reader can also be an author (i.e., a creator of the famous Encyclopedia). Another example is new presentation systems like Prezi, which are so different from PowerPoint and allow teachers and students to be the creators of their ideas and visualize connections in an unlimited conceptual space. A final example is the funny avatars that vocalize speech products at voki.com. Teachers can find the 10-30 most popular Web 2.0 tools at http://edudemic.com/2012/10/best-web-tools-2012/. As an aside, there is an entire "Second World" program, where avatars are creating their own world and live in this "created" world: They create their businesses, homes, and communities without the necessity to be located in a certain geographical area. Pedagogically, all of these new tools can be used to involve and inspire the user to be a co-creator or creator. There are also creativity-enhancing tools (not only books), which means the Internet is uniting the process of learning with creativity to form creative learning: It is a pure Creative Pedagogy principle in action.

Since creativity itself is of great interest to people, there may be tidbits of creativity methods and techniques that can teach learners to be more creative in every subject lesson: Students might attend another lesson just to learn more about creativity. As far as language programs are concerned, speech creativity is limitless. Allow your students to speak and write without criticism (the brainstorming technique): This will move them closer to true fluency, active elaboration, exceptional originality, and flexibility. Teach them first what fluency is and how to work on fluency in FL learning. Imagine that you create exercises for originality, and then see how students begin to create original statements in FL. Imagine that you demonstrate 
what flexibility is, then train flexibility, and only after that observe how students improve their presentation in FL. The results will astound you.

Creativity research has generated about 5,000 methods and techniques to boost creativity. Teach students a method a day, and they will stay in line for your class. If a person is creative, their FL learning moves much faster, and students will begin to create their own methods for learning. Oh, how excited they become when they find they can learn or teach 200 words a day!

\section{Concluding Notes}

It is interesting to see how the best educational practices in various fields have finally arrived at the ideas of Creative Pedagogy. Now, the concepts of Creative Pedagogy are even applicable in music (Mazzola, Park, \& Thalmann, 2011). Moreover, a very talented educator, Professor Anuradha Joshi from India, applied the principles of Creative Pedagogy to the seemingly very boring subject of pharmacology (drugs in medicine) and, as a result, her students blossomed. She has since been invited to Finland, the United States, and Asian countries to show other college professors how to make learning much more engaging and, therefore, much more efficient. The most recent news from her made the author even happier: one of her students wrote an article on drugs in poetic form. The author knows only one case from the history of science, when a scientist in Chemistry sent an article to the Chemistry Journal - in poetic form. After some thinking they decided to publish it - it was the first article in their Journal! Now the Pharmacology student can have the same experience. The second good news is Professor Joshi is nominated for the Women Achiever's Award this year again in India. Bravo to the second generation of Creative Pedagogy stars, and their students - the third generation. Are they now considered the grand children in Creative Pedagogy?

The learner and the teacher should be creators, exactly as Arthur Koestler said (see the epigraph). A bright example of creativity developed first, and other skills, like music composition skills acquired later, came from one of my first students, Tim (Timothy) Wilkins, who received his first Certificate of Genius at the age of 6 (in 1995), then came to School of Genius for the second time at 8, received his second Certificate of Genius (he is the only person in the world with two certificates), and in May 2013, graduated from the Composition Department of the university and immediately received a Fulbright scholarship to research and compose music in Bulgaria. Bravo, Tim!

It is even more interesting to see how the Internet has developed from Web 1.0 Tools (mostly information resources) to Web 2.0 Tools that involve the user as a communicator and co-creator, and finally to Web 3.0 Tools that will "create the content" and "augment the content" in a human/machine collaboration (Coleman, 2011). The user/learner should be a creator. Finally, it is strikingly pleasant to see some pioneering business companies embark on the most challenging (but worthy) journey in which they declare the human being's (employee) development to the maximum of their human potential to be as important as the financial success of the company (known as "the dual bottom line") (EnPro Industries, 2013), 
aiming to create a creator. All theoretical and practical things considered in progress, Creative Pedagogy ( + Creative Andragogy $=$ Creagogy) (Aleinikov, 1998) continues to address the issues of problem students (children and adults) as well as help other students to aim high. Teachers (instructors and professors) who learn to be creative teachers earn accolades from schools, colleges, institutes, universities, and their Ministries of Education.

It should be noted that many people do not know what Creative Pedagogy is, but they intuitively move in the right direction, which was explained and predicted by Creative Pedagogy. This is acceptable, too, and I am happy for them. Analogically, until they learned poetry, many did not know that they spoke in prose all the time. Moreover, many do not know that they use idioms, clichés, neologisms, and more; they just speak. Creativity, like speaking, is natural for human beings, and if one is creative, one can speak. However, since creativity is teachable, a more creative (trained) person will always perform better than one who is just naturally creative (non-trained), much like how a trained mixed martial arts champion will always win over a naturally aggressive village hooligan. Therefore, creativity training for students and teachers is a must. Finally, it should be remembered that the more creativity we have (as opposed to destructivity), the more humane we become (Aleinikov, 1999a)

Naturally, as with all other types of research, Creative Pedagogy has its limitations, which can be seen as perspectives to develop. Until now, it has only been tested on students between the ages of 6 and 76. Why not try it earlier and later? Moreover, it has mainly been used in two languages, Russian and English (though translated into 7 more), but there is, as yet, no research on how the language and culture follow or influence the basic principles of Creative Pedagogy.

The next limitation and perspective is the subject matter. The subjects known so far to apply Creative Pedagogy include elementary education, languages, math, science, geography, music, psychology, history, education, and pharmacology. What about the other hundreds of teaching subjects? Chemistry? Physical Education? Social Sciences? The author has received some letters from Iran where a social sciences teacher had applied Creative Pedagogy, but there is no research data on this application. Recently, an article on brain research has been published that corroborated the presence of a specific zone in the brain that was very well developed and active in creative people (such as designers, producers, and artists) as compared with the control group. We can only imagine what could be done if we measured this zone before the program, during the program, and after the program. Thus, the scope for further research is huge: Creative Pedagogy is only 30 years old, and it has a long way to go.

\section{Acknowledgments}

The author would like to thank everyone who participated in my classes; all my dedicated students, teachers, professors, editors, colleagues, and the Directors and web designers for enormous courage - it is so difficult to be the first. You are the heart of this transformation process and you always be in my heart. Last but not least is my family: Elena, who was a 
co-creator of the theory, but passed away in 2004 (God bless her soul), and, now, Viktoriya and my little son, Rimond (a formidable inventor and everyday inspiration). Thank you for doing your best in the difficult process of creation, for your support, for sacrificing your time, for the positive emotional response, and the exciting lively overall environment. This is solid proof of Creative Pedagogy working at home, in school, at work, in the country, and globally.

\section{References}

Aleinikov, A. G. (1995, October). Hyper Efficient Language Program-"First HELP + 2,000." Sharing the Dream. Paper presented at NAFSA: Association of International Educators, Region VII Conference, Memphis, Tennessee. Washington, DC: NAFSA.

Aleinikov, A. G. (1996). Super Effective Communication. Alabama English, Spring (8), 28-31.

Aleinikov, A. G. (1997). Openness - It's that simple. Republished by Teaching for Success (TFS) as "The TFS Classic" 2007; 8 (5) and (6), p. 15. First published in 1997.

Aleinikov, A. G. (1998, July). Creative pedagogy + creative andragogy = Creagogy (How to create a creator). Paper presented at the IX International Conference on Creativity in Universities and Colleges. Midland, Michigan: The Alden B. Dow Creativity Center.

Aleinikov, A. G. (1999a). Humane creativity. In S. Pritzker \& M. Runco (Eds.), Encyclopedia of creativity (Vol. 1, Ed. 1, pp. 837-844). San Diego and London: Academic Press.

Aleinikov, A. G. (1999b). Mega-creator: From creativity to mega-, giga-, and infi-creativity. Montgomery, AL: MIMII.

Aleinikov, A. G. (2001a). Latvia. In R. Marlow-Ferguson (Ed.), World Education Encyclopedia, 2, 770-777. Detroit, New York, San Diego, etc.: Gale Group.

Aleinikov, A. G. (2001b). Uzbekistan. In R. Marlow-Ferguson (Ed.), World Education Encyclopedia, 3, 1524-1536. Detroit, New York, San Diego, etc.: Gale Group.

Aleinikov, A. G. (2002). MegaCreativity: Five steps to thinking like a genius. Cincinnati, $\mathrm{OH}$ : Walking Stick Press.

Aleinikov, A. G. (2003). Genius education methodology helps creating a nation of geniuses: New horizons, awards and rewards in creative and innovative education. Retrieved from: http://www.humiliationstudies.org/news-old/archives/000039.html on Mar 10.2020.

Aleinikov, A. G. (2008). How GEGA (Genius expectations - genius achievements) supercharges learning. Teaching for Success, 19(4), 1-2.

Aleinikov, A. G. (2013a). Creative pedagogy. In E. G. Carayannis (Ed.), Encyclopedia of creativity, invention, innovation, and entrepreneurship (pp. 326-339). New York: Springer.

Aleinikov, A. G. (2013b). Creative linguistics. In E. G. Carayannis (Ed.), Encyclopedia of creativity, invention, innovation, and entrepreneurship (pp. 299-316). New York: 
Springer.

Aleinikov, A. G. (2013c). Creativity. In E. G. Carayannis (Ed.), Encyclopedia of creativity, invention, innovation, and entrepreneurship (pp. 391-402). New York: Springer.

Aleinikov, A. G. (2013d). Genius. In E. G. Carayannis (Ed.), Encyclopedia of creativity, invention, innovation, and entrepreneurship (pp. 790-805). New York: Springer.

Aleinikov, A. G. (2013e). Novology. In E. G. Carayannis (Ed.), Encyclopedia of creativity, invention, innovation, and entrepreneurship (pp. 1392-1400). New York: Springer. See also other works of the author on Novology since 2001.

Aleinikov, A. G. (2013f). Science of creativity. In E. G. Carayannis (Ed.), Encyclopedia of creativity, invention, innovation, and entrepreneurship (pp. 1574-1592). New York: Springer.

Aleinikova, E.N. \& Aleinikov, A. G. (1991) The stages in creativity development: options for universalizing the methods. In Shmakova, L. E., Malovichko, V. S., (Eds). Creative Management. Vol. 1. Moscow: Creator, Center for creative research, Russian Academy of Sciences, pp. 269-96. russ. Алейникова, Е. Н., Алейников, А.Г. Этапы формирования творчества: возможность универсализации приемов. Креативный менеджмент.

Coleman, D. (2011). What is Web 3.0, and why do you care. Retrieved 1 April, 2013 from http://www.cmswire.com/cms/social-business/what-is-web-30-and-why-do-you-care-01 3072.php

EnPro Industries. (2013). The dual bottom line. Retrieved 12 June, 2013 from http://www.youtube.com/watch?v=-mDNTqGKIMA

Ghonsooly, B., \& Showqi, S. (2012). The effects of foreign language teaching on creativity. English Language Learning, 5(4), 161-167. Retrieved 13 November, 2013 from http://dx.doi.org/10.5539/elt.v5n4p161.

Gordon, W. J. J. (1961). Synectics. New York: Harper \& Row.

Lange, L. (1888). Neue Experimente über den Vorgang der einfachen Reaction auf Sinneseindrücke. Philosophische Studien, 4, 479-510. Retrieved 10 March, 2020 from https://psychclassics.yorku.ca/LangeL/NewExperiments.pdf

Mazzola, G., Park, J., \& Thalmann, F. (2011). Musical creativity: Strategies and tools in composition and improvisation. Heidelberg, Germany: Springer-Verlag Berlin $\begin{array}{lllll}\text { Heidelberg. } & \text { Retrieved } & 12 & \text { January, } & 2020\end{array}$ http://dx.doi.org/10.1007/978-3-642-24517-6

Moliako, V. A. (1985). Technical creativity and labor upbringing. Newness in life, science and technology. Series: Pedagogy and Psychology, 6, 20-1.

Ramos, S. (2013). Genius Education Methodology: Mystery or magic? Retrieved 2 April, 2013 from

http://www.creativityventures.com/index.php/articles/genius_education_methodology_ 
mystery_or_magic/

Uznadze, D. N. (1961). The Experimental Basis of Psychological Ustanovka (Mindset). Tbilisi. russ. Узнадзе Д. Н., Экспериментальные основы психологии установки, Тбилиси. Note: The concepts of установка (Russian), mindset, and attitude have slight differences, but for now, we will use their common understandings.

Zwicky, F. (1957). Morphological Analysis. Berlin: Springer-Verlag.

\section{Copyright Disclaimer}

Copyright for this article is retained by the author(s), with first publication rights granted to the journal.

This is an open-access article distributed under the terms and conditions of the Creative Commons Attribution license (http://creativecommons.org/licenses/by/3.0/). 